\title{
Effect of Milk Protein Hydrolysate on Some Hematological Parameters of Type II Diabetic Rats
}

\author{
Mahmoud Ibrahim El-Sayed ${ }^{1}$, Sameh Awad ${ }^{2}$, Mokhtar Yousef ${ }^{3}$, Abdelmonem Wahba ${ }^{2}$, \\ Aisha El Attar ${ }^{2}$, Mostafa Zedan ${ }^{1}$ \\ ${ }^{1}$ Department of Dairy Technology Research, Food Technology Research Institute, ARC, Giza, Egypt \\ ${ }^{2}$ Department of Dairy Science and Technology, Faculty of Agriculture, Alexandria University, Alexandria, Egypt \\ ${ }^{3}$ Department of Environmental Studies, Institute of Graduate Studies and Research, Alexandria University, Alexandria, Egypt
}

Email address:

mahmoud_im1981@yahoo.com (M. I. El-Sayed)

\section{To cite this article:}

Mahmoud Ibrahim El-Sayed, Sameh Awad, Mokhtar Yousef, Abdelmonem Wahba, Aisha El Attar, Mostafa Zedan. Effect of Milk Protein Hydrolysate on Some Hematological Parameters of Type II Diabetic Rats. International Journal of Homeopathy \& Natural Medicines. Vol. 5, No. 1, 2019, pp. 18-29. doi: 10.11648/j.ijhnm.20190501.14

Received: March 8, 2019; Accepted: April 13, 2019; Published: May 20, 2019

\begin{abstract}
Milk protein-derived bioactive peptides could be used in human nutrition in both newborns and adults, since they are claimed to be health-improving components that can be used to reduce the risk of disease or to enhance certain physiological functions. This study investigated the effect of oral intake of milk protein concentrate (MPC) and milk protein concentrate hydrolysate (MPCH) on body weight, organ relative weight, and hematological parameters in alloxan-induced diabetes rats. The animals were divided into six major groups after stabilization of diabetes for one week. Diabetic and nondiabetic rats groups were received intra-gastric dose of MPC or MPCH $(150 \mathrm{mg} / \mathrm{kg} \mathrm{B.W})$ for six weeks. Feed treatment by MPC and MPCH significantly $(P<0.05)$ increased the final body weight of normal rats and improved the body weight of diabetic rats and significantly protective $(p<0.05)$ the liver, kidney, heart and lung of normal rats and reduced the fallers of these organs in diabetic rats. The diabetes groups treated by MPCH showed improvement in RBC, Hb, Ht and PLT values. Meanwhile WBC not affected. The oral intake of MPCH protected the normal range of Lymphocytes and S. Nutrophils in healthy and diabetic rats. The oral intake of MPCH caused significant $(P<0.05)$ decrease of Monocytes in diabetic and nondiabetic rats, while the oral intake of MPC had no affected on Monocytes of diabetic and non-diabetic rats. MPC and MPCH reduced the harmful effect of T2D on body weight, organs weights of rats, and improvement most hematological parameters of normal and diabetes rats.
\end{abstract}

Keywords: Milk Protein, Protein Hydrolysate, Bioactive Peptides, T2 Diabetes

\section{Introduction}

Diabetes is prevalent in about $3 \%$ to $5 \%$ of the population in industrialized countries. Diabetes mellitus (DM) is a metabolic and chronic disease with a multifactorial etiology, caused by defects in insulin secretion and/or action and presenting hyperglycemia as a common manifestation [1]. Multiple metabolic disorders, including impaired lipid and lipoprotein metabolism, oxidative stress, subclinical inflammation, and vascular endothelial dysfunction, are common in DM [2].The major forms of diabetes, type 1 and type 2 diabetes, contribute at about 10 percent and 90 percent, respectively [3]. The worldwide incidence of type2 diabetes is increasing. It was estimated in 2000 that there were 171 million diabetics, while incidences for 2030 are estimated to reach 366 million people [4]. Type II diabetes (DM2) or non- insulin-dependent diabetes mellitus (NIDDM) is characterized by impaired insulin secretion or insulin resistance. DM2 is usually associated with obesity and hereditary disposition and it is the most common form of diabetes, affecting $90-95 \%$ of cases [5]. Loss of weight and increase in physical activity reduces the incidence of T2D and its vascular complications partially via anti-inflammatory mechanism. Diabetes is not only affected by the amount of dietary intake but also by the type of diet. The consumption of dairy products has been associated with a reduction of the 
DM risk and an improvement in metabolic health [6]. The beneficial effects of milk have been related to its components such as calcium and whey proteins [7, 8]. Milk proteins are considered as the most important sources of bioactive peptides. Bioactive peptides show significant potential for use in health management strategies, particularly as components of drugs and functional foods for diabetes treatment [9]. The beneficial health effects of bioactive peptides are classified as cytomodulatory, mineral binding, antimicrobial, immunomodulatory, blood-pressure lowering (Angiotensin-converting enzyme ACE- inhibitory), antithrombotic, antioxidant and opioid like, in addition to cholesterol-lowering and enhancers of mineral absorption/bioavailability [10-14]. Bioactive peptides encrypted in major milk proteins are latent within the sequence of the parent protein molecule. Milk-derived bioactive peptides can be released during gastrointestinal digestion, food processing or by enzymatic and bacterial fermentation [15]. In relation to their mode of action, bioactive peptides may reach target sites at the luminal side of the intestinal tract, or after absorption, in peripheral organs [16]. Milk protein-derived bioactive peptides could be used in human nutrition in both newborns and adults, since they are claimed to be health-improving components that can be used to reduce the risk of disease or to enhance certain physiological functions [17]. Milk protein hydrolysates enhanced immunity in mice by stimulating host immunity, probably by increasing the weight of certain immune system organs, improving the level of hemolysin in serum, and enhancing the phagocytosis of macrophages [18]. The aim of this study was to investigate the biological effects of milk protein concentrate (MPC) and milk protein concentrate hydrolysate $(\mathrm{MPCH})$ which contains bioactive peptides on body weight, relative organs weight and hematology alternation in alloxan-induced diabetic rats.

\section{Materials and Methods}

\subsection{Animals}

Sixty male healthy albino rats with weight ranged from 190 to $210 \mathrm{~g}$ were obtained from Institute of Graduate Studies and Research (IGSR), Alexandria University, Egypt. The local committee in Alexandria University, Egypt, approved the design of the experiments, and the protocol conforms to the guidelines of the National Institutes of Health (NIH).

\subsection{Materials, Chemicals and Reagents}

Cow milk protein concentrate (MPC) were obtained from Fonterra Ltd, Auckland, New Zealand, and its typical analysis was: Protein $69.89 \%$, lactose $17 \%$, minerals $7.2 \%$, moisture $4.6 \%$ and milk fat $1.4 \%$. Trypsin $2000 \mathrm{U} / \mathrm{g}$ (EX pancrease) from Loba Chemie, India. Alloxan was obtained from Alpha Co. India, dissolved in saline solution $(0.9 \%$ sodium chloride, $\mathrm{pH} 7$ ). The dose of alloxan used was $120 \mathrm{mg} / \mathrm{kg} \mathrm{BW} /$ day. The chosen dose of alloxan is well documented to induce diabetes in rats, according to the previous studies of Mansour et al. [19]; Sheweita et al.[20].

\subsection{Preparation of Milk Protein Hydrolysates}

Preparation of milk protein hydrolysate was carried out according to the method of Otte et al, [21]. Protein solutions $(2 \% \mathrm{w} / \mathrm{w}$ on protein basis) were made by dispersion of approximately $2.85 \mathrm{~g}$ of milk protein concentrate (according to the protein content) in $100 \mathrm{ml}$ of distilled water, and stirring for $1 \mathrm{~h}$ at room temperature. Solutions were hydrated overnight at $5^{\circ} \mathrm{C}$, after that, the $\mathrm{pH}$ was adjusted to 7.0 and 7.5 by $1 \% \mathrm{NaOH}$ solution. A pretreatments using Trypsin enzyme solution $\left(3.2 \mathrm{U} \mathrm{mL}^{-1}\right)$ was made in distilled water immediately prior to use as recommended by El-Sayed et al, [22]. For each hydrolysis experiment, $100 \mathrm{~mL}$ of protein solution was incubated at $40^{\circ} \mathrm{C}$ for $3,6,9,20$ and $24 \mathrm{~h}$. Enzyme was inactivated by heating at $90^{\circ} \mathrm{C}$ for $15 \mathrm{~min}$, and then cooling for $20 \mathrm{~min}$ in ice bath and then centrifugation (Sigma centrifuge 113 VWR International, Germany) for 10 min at $10,000 \mathrm{xg}$, the supernatant was used for further analyses as described below.

\subsection{Sodium Dodecyl Sulphate Polyacrylamide Gel Electrophoresis (SDS-PAGE)}

SDS-PAGE technique was carried out using the discontinuous buffer system described by Laemmli [23], and mentioned by Hames and Rickwood [24].

\subsection{Analysis of Peptides by Reverse-Phase High-Performance Liquid Chromatography (RP-HPLC)}

Separation of the peptide extracts was carried out using a HPLC system (Agilent Technologies 1260) according to the method described by Awad, Lüthi-Peng, \& Puhan [25].

\subsection{Animals and Treatments}

The animals were housed in cages under proper environmental conditions. Animals were housed 5 per cage and kept on commercial die (pellets). The chemical analysis of the pellets according AOAC [26] showed that they contained $17.5 \%$ crude protein, $14.0 \%$ crude fiber, $2.7 \%$ crude fat and $2200 \mathrm{Kcal} / \mathrm{kg}$ diet), tap water provided ad libitum and kept for two weeks for acclimatization and maintained at $25 \pm 1^{\circ} \mathrm{C}$ with $12 \mathrm{~h}$ dark and light cycle [27]. The protein concentrate hydrolysates were evaluated by RPHPLC and bitter taste. Sample prepared by trypsin $8 \mathrm{X}$ at $\mathrm{pH}$ 7.5 and $40^{\circ} \mathrm{C}$ for $20 \mathrm{~h}$ (Fig.4), was selected to be used in animal treatments. The experimental period was six weeks after stabilization of diabetes for one week and the animals were divided into six major groups as following:

Group I: ten rats were kept as a control.

Group II: ten rats were kept as a diabetic control.

Group III: ten rats were received intra-gastric dose of milk protein concentrate

$800 \mathrm{mg} / \mathrm{kg} \mathrm{B.W} /$ day (MPC group).

Group IV: ten rats were kept as a diabetic received intra- 
gastric dose of milk protein concentrate $800 \mathrm{mg} / \mathrm{kg} \mathrm{B.W} /$ day (MPCD group).

Group V: ten rats were received intra-gastric dose of milk protein concentrate hydrolysate $800 \mathrm{mg} / \mathrm{kg}$ B.W/ day (MPCH group).

Group VI: ten rats were kept as a diabetic received intragastric dose of milk protein concentrate hydrolysate $800 \mathrm{mg} /$ $\mathrm{kg} \mathrm{B.W/} \mathrm{day} \mathrm{(MPCHD} \mathrm{group).}$

\subsection{Body Weight and Organs Weight}

At first and end of the experimental period, body weights of rats were recorded. Animals were anesthetized with ether and sacrificed. Liver, kidney, heart, lung, spleen, testes, brain and pancreas were immediately removed and weighted. Then the organs weight/body weight ratio was calculated. The relative weight of organs (\%) was calculated as $\mathrm{g} / 100 \mathrm{~g}$ body weight.

\subsection{Hematological Parameters}

The blood samples were collected in two tubes: one containing EDTA (anti-coagulant) and the other containing Heparin (anti-coagulant). Non coagulated blood by EDTA was tested shortly after collection by Particle counter (from ERMA INC.-Tokyo. Model PCE-210) for measuring total erythrocyte count (TEC), platelets count (PLT), hemoglobin $(\mathrm{Hb})$, hematorit $(\mathrm{Ht})$, red cell distribution width (RDW), mean cell volume (MCV), mean corpuscular hemoglobin $(\mathrm{MCH})$ and mean corpuscular hemoglobin concentration (MCHC) total leukocyte counts (TLC), white blood cell count (WBC), lymphocytes, segmented nutrophils, monocytes and eosinophils.

\subsection{Statistical Analysis}

The data were analyzed by a general linear model procedure of the Fisher's protected least-significant difference (PLSD) test using SAS, 2004 (SAS Institute, Inc., Cary, NC) [28]. This test combines ANOVA with a comparison of differences between the means of the treatments at the significance level of $\mathrm{P} \leq 0.05$. Correlations were calculated using Pearson's correlation coefficient.

\section{Results}

\subsection{Poly Acrylamide Gel Electrophoresis (PAGE)}

Thus in this study, SDS- PAGE technique was applied in analysis of MPC as well as in monitoring their proteolysis rate by trypsin. Figure (1, 2 and 3$)$ illustrated the electrophoretic patterns of trypsin treated-milk protein concentrate at $2 \mathrm{X}, 4 \mathrm{X}$, and $8 \mathrm{X}$ enzyme for 3, 6, 9, 20 and 24 $\mathrm{h} / \mathrm{pH} 6.8$ and 7.5. It is clear that the behavior of MPC was not affected by enzyme action until nine hours. While after 20 and 24 hours of treatments, there were few and very small peptides, having MW less than $20 \mathrm{KD}$, are appearing on the gel. These peptides were differences in their intensities and migration positions. The obtained results concluded that the action of enzyme on MPC was affected by the time, $\mathrm{pH}$ and enzyme: substrate ratio.

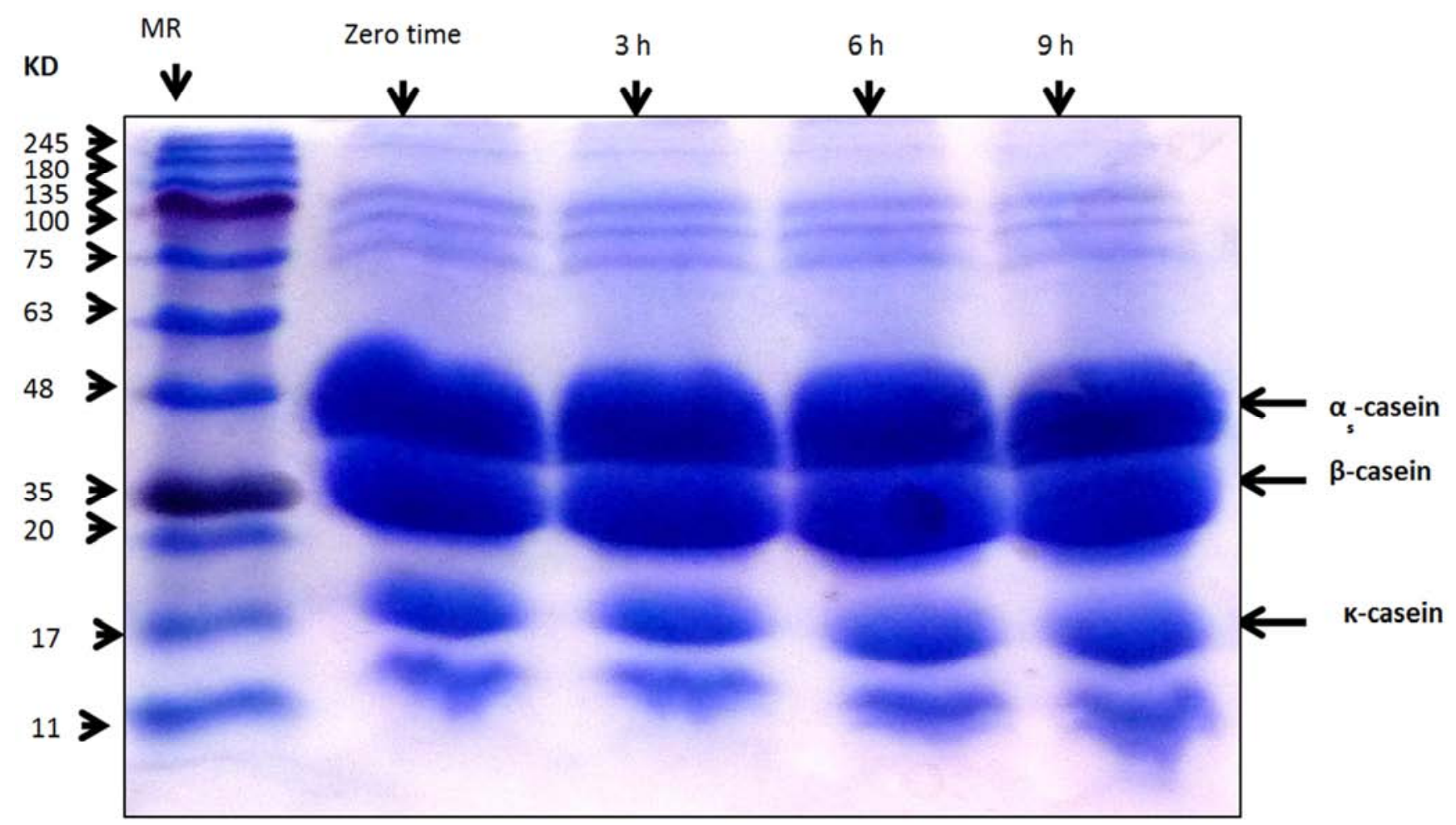

Figure 1. SDS-PAGE of milk protein concentrate and milk protein concentrate treated by trypsin $(2 X)$ at pH7.5 for 3,6 and $9 \mathrm{~h} / 40^{\circ} \mathrm{C}$. 


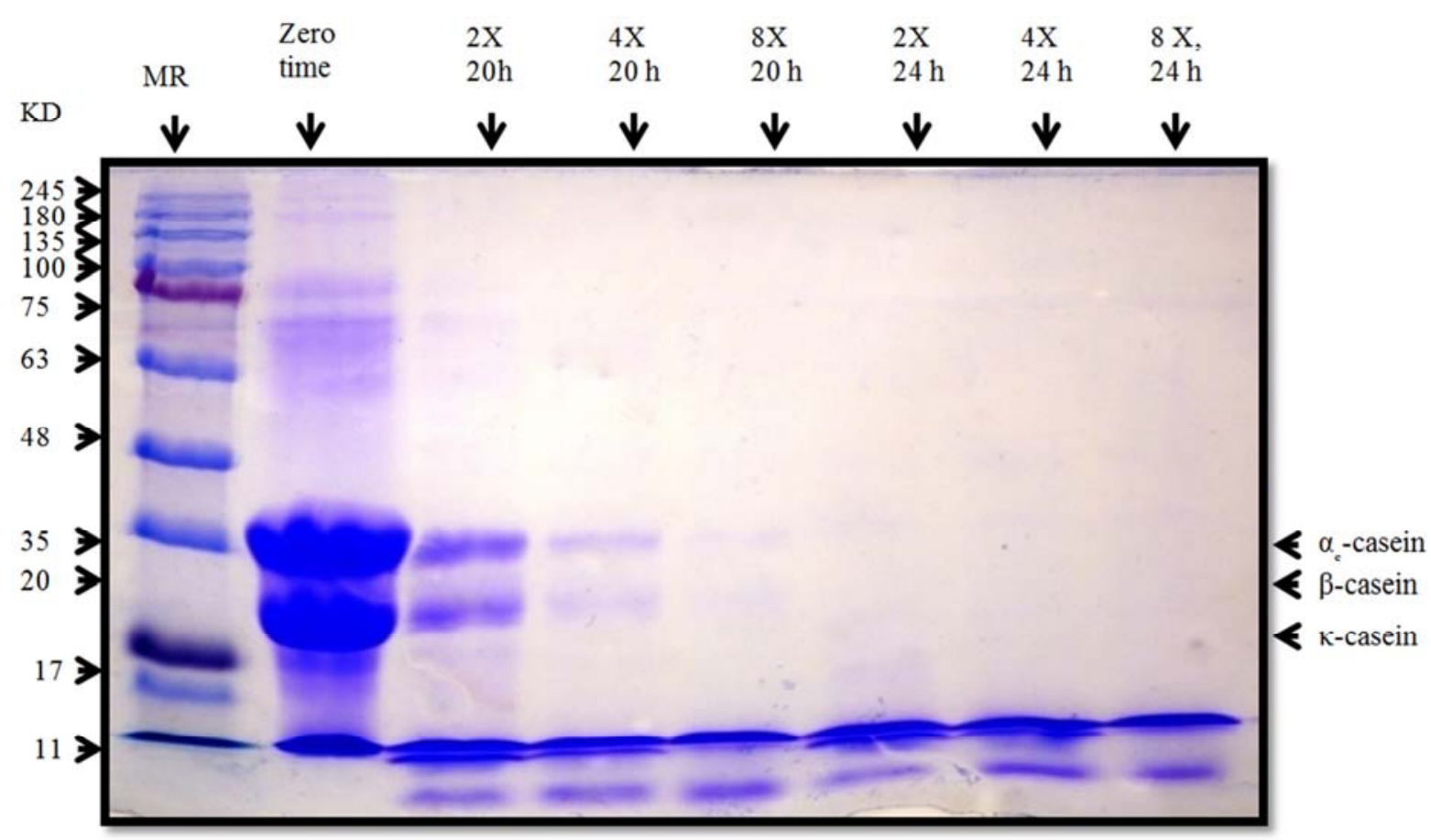

Figure 2. SDS-PAGE (12.5\% T) of milk protein concentrate and milk protein concentrate hydrolysates no1, 2, 3, 4, 5 and 6 (samples treated by trypsin 2,4 and $8 X$ at $p H 6.9$ and $40^{\circ} \mathrm{C}$ for 20 and $24 \mathrm{~h}$ respectively). MR: standar protein marker.

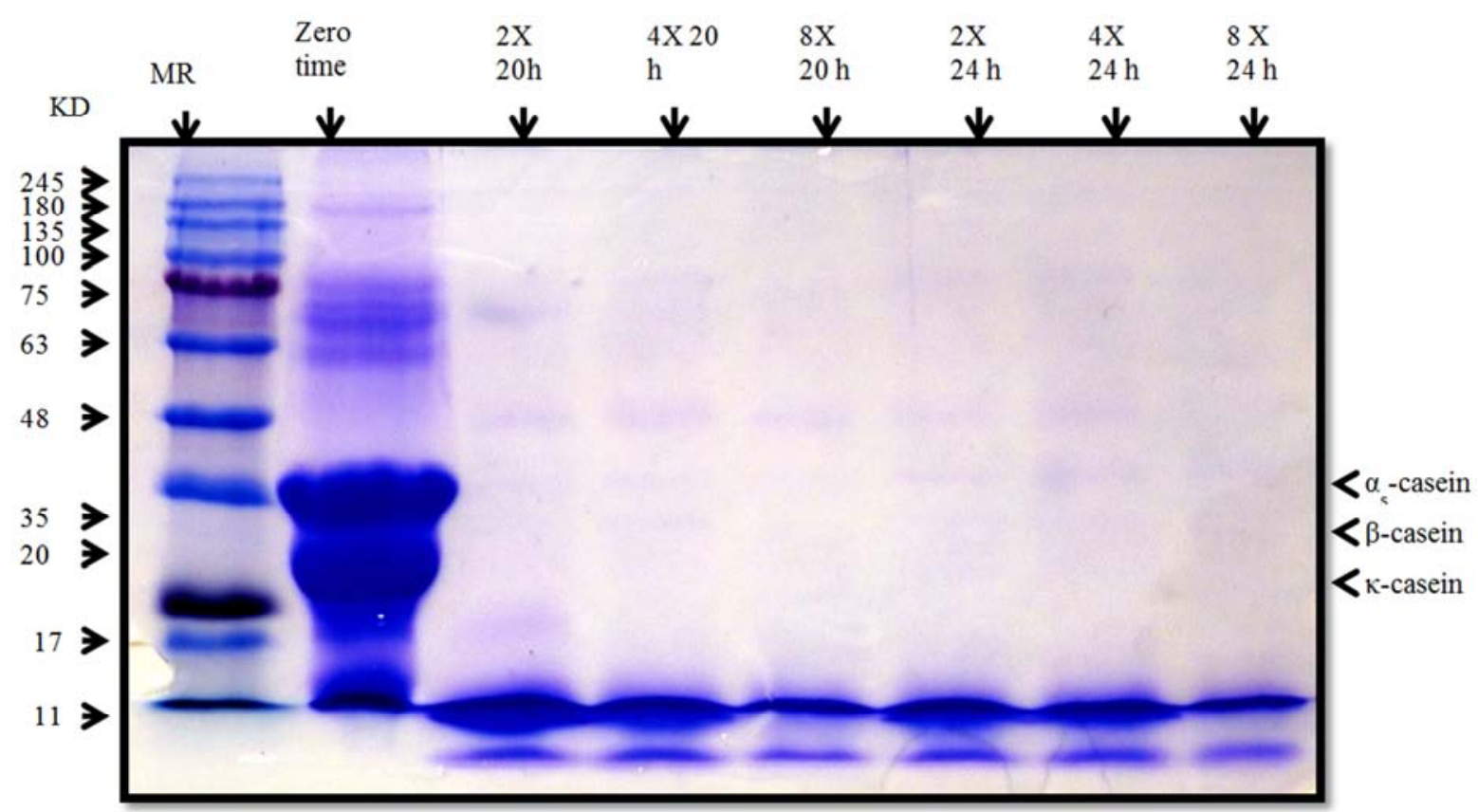

Figure 3. SDS-PAGE (12.5\% T) of milk protein concentrate and milk protein concentrate hydrolysates no 7, 8, 9, 10, 11 and 12 (samples treated by trypsin 2,4 and $8 X$ at $p H 7.5$ and $40^{\circ} \mathrm{C}$ for 20 and 24 h respectively). MR: standar protein marker.

\subsection{Reverse Phase High Performance Liquid Chromatography (RP-HPLC)}

In peptide chemistry, HPLC has gained importance as an analytical tool because of its exquisite sensitivity, speed, and resolving power. The most useful method for peptide separation is HPLC. Commercially available reversed-phase columns allow rapid separation and detection of their hydrophilic and hydrophobic characteristics. The hydrolysate of all MPC treatments were elated by RP-HPLC, chromatograms showed that the trypsin $(2 \mathrm{x}, 4 \mathrm{x}$ and $8 \mathrm{x})$ produced more peptides after $24 \mathrm{~h}$ than after $20 \mathrm{~h}$ of incubation, and the hydrolysate at $\mathrm{pH} 7.5$ produced small peptides than at $\mathrm{pH}$ 7. According to the evaluation of bitterness and RP-HPLC, the treatment of trypsin $8 \mathrm{X}$ at $\mathrm{pH}$ 7.5 and $40^{\circ} \mathrm{C}$ for $20 \mathrm{~h}$ (Figure 4) was selected to use in the experiment. 


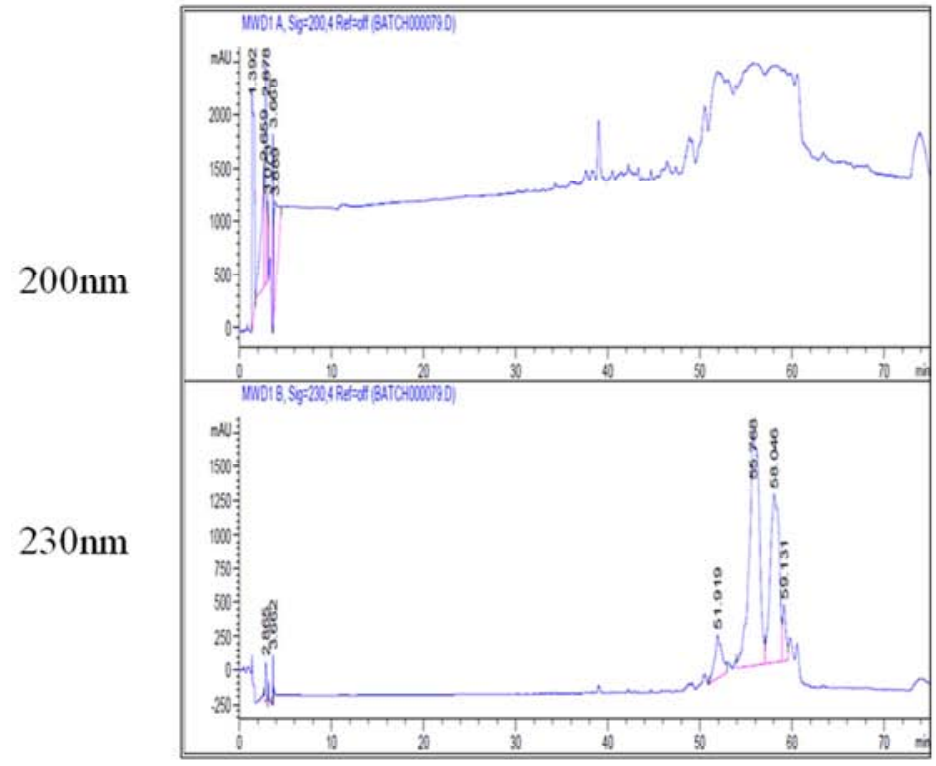

(A)

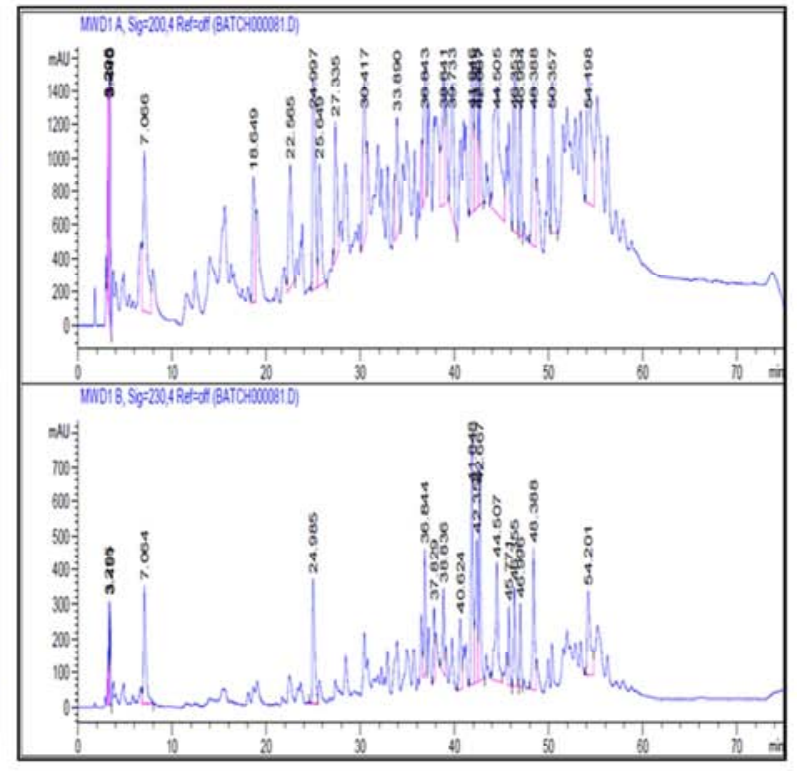

(B)

Figure 4. RP-HPLC pattern of (A) milk protein concentrate, (B) milk protein concentrate hydrolysate MPCH treated by trypsin $8 X$ at $p H 7.5$ and $40^{\circ} \mathrm{C}$ for 20h).

\subsection{Body Weight and Relative Organs Weight of Diabetic and Non-Diabetic Rats}

Figure (5, 6 and 7) represent body weight and relative weight of liver, kidney, heart, lung, brain, testes, spleen and pancreas of male diabetic and non-diabetic rats treated by oral intake of MPC and MPCH. Treatment with alloxan alone caused a significant $(p<0.05)$ decreasing in body, pancreas weights, and significant increasing in liver, kidney, heart and lung relative weights in comparison with control. Meanwhile, no significant $(p>0.05)$ differences were found in brain, spleen and testes weights of diabetic rats. On the other side, the treatments with MPC and MPCH showed a significant $(P<0.05)$ increasing in the final body weight of normal and diabetic rats when compared to its control, meanwhile the body weight of diabetic rats treated with MPC or MPCH was not reached the weight of normal control. The treatment by oral intake of MPCH significantly $(P<0.05)$ reduced the liver weigh in diabetic rats when compared with diabetic control, however oral intake of MPC has no effect. On the other hand, oral intake of MPC and MPCH not affected the liver weight in normal rats compared with the control group. The obtained results showed that the oral intake of $\mathrm{MPCH}$ caused significant $(P<0.05)$ increase in pancreas weight of diabetic rats compared with diabetic control, while MPC has no effect. Also, there was no significant $(P>0.05)$ difference in pancreas weight of normal rats treated with oral intake of MPC and MPCH. On the other side, the oral intake of MPCH significantly $(P<0.05)$ reduced kidney and lung weights of diabetic rats compared with that in diabetic control, while there was no significant $(P>0.05)$ difference of kidney and lung weights between diabetic rats treated by MPC and diabetic control. Treatments by MPC or MPCH have no effect on kidney and lung weights of normal rats compared to that of control. There were no significant $(P>0.05)$ difference in heart, testes, brain, spleen of diabetic rats treated with MPC and MPCH when compared with that of diabetic control. Also, there were no significant $(P>0.05)$ difference in heart, testes, brain, spleen of normal rats treated with MPC and $\mathrm{MPCH}$ when compared with that of normal control group.

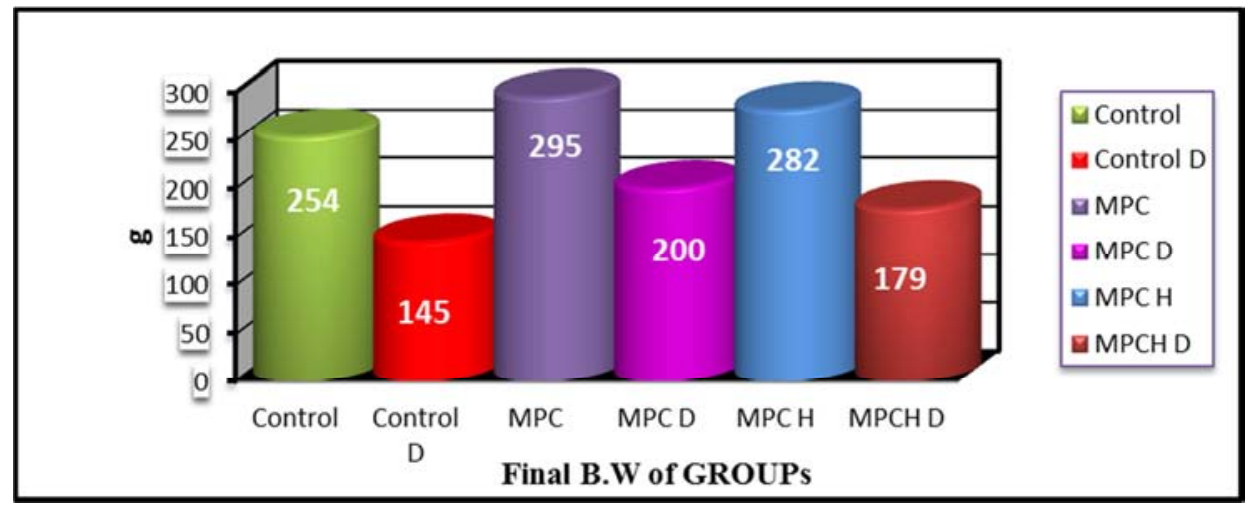



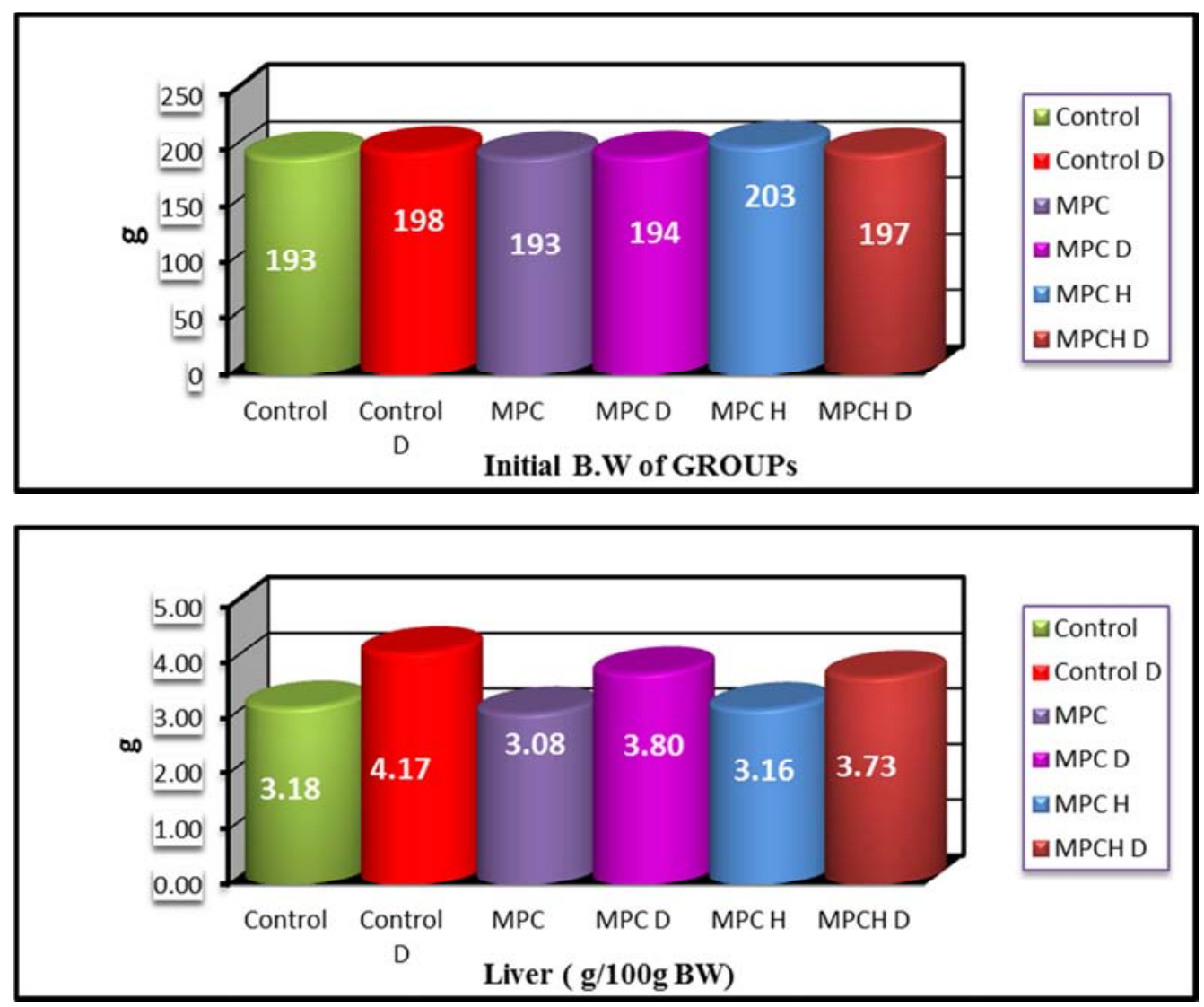

Figure 5. Changes in body weight (BW; g) and relative weight $(\mathrm{g} / 100 \mathrm{gm})$ of liver, of male diabetic (D) and non-diabetic rats treated with milk protein concentrate (MPC) and milk protein concentrate hydrolysate (MPCH).
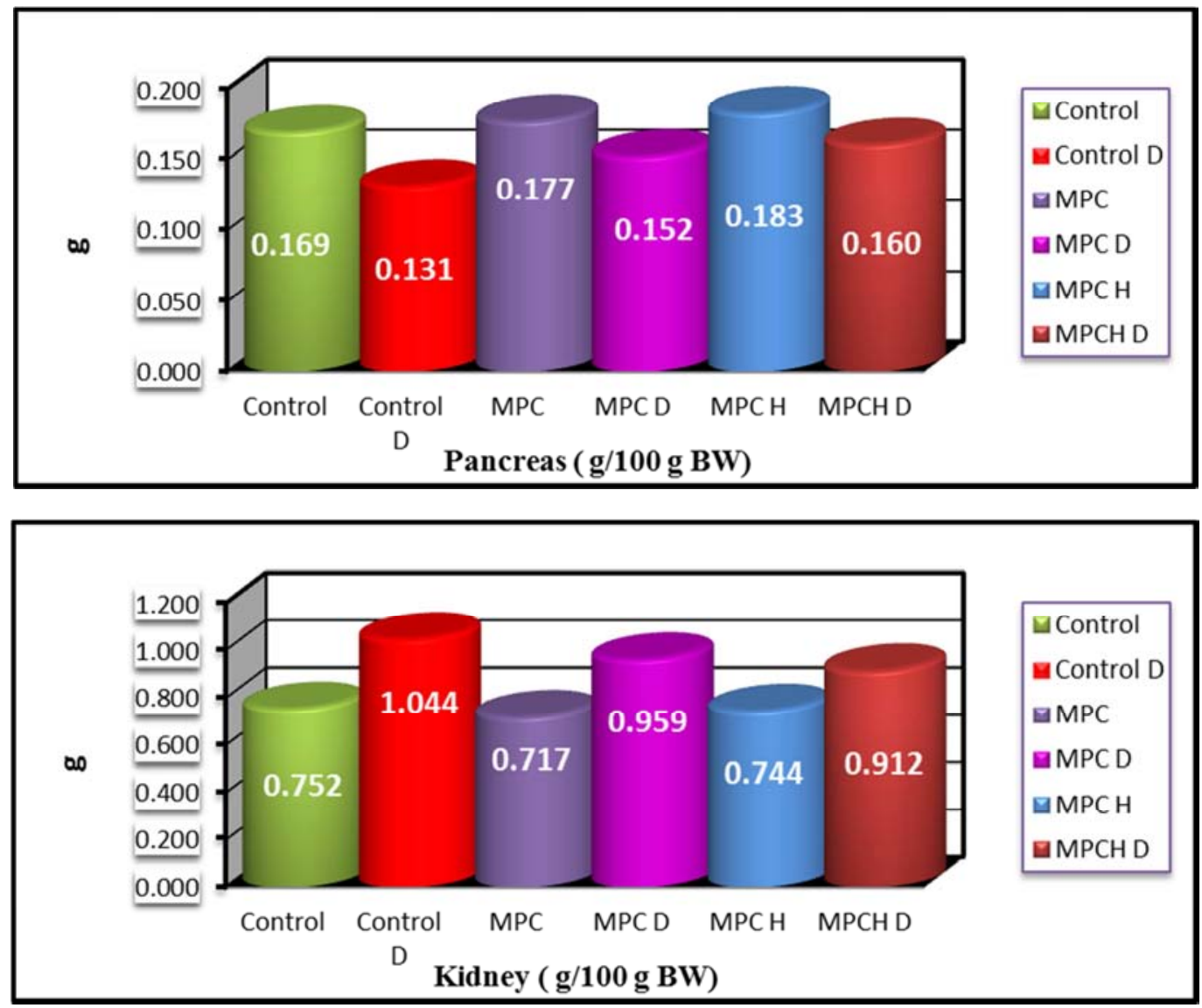


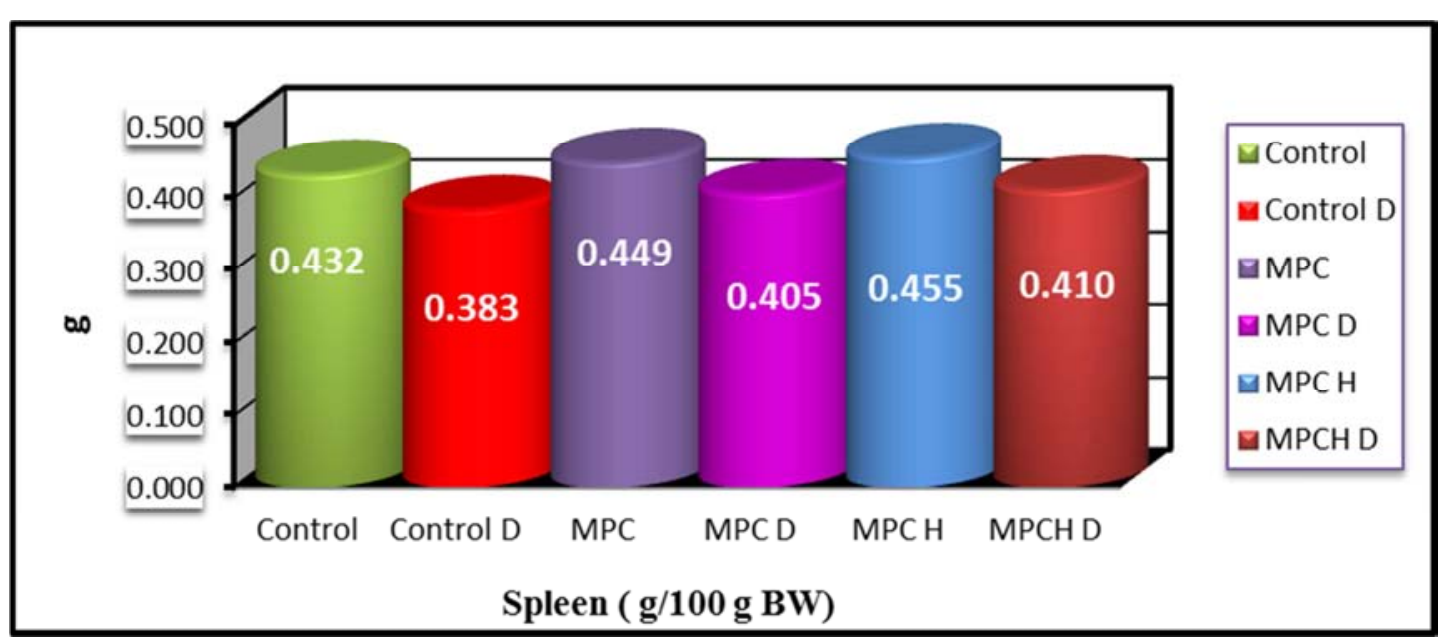

Figure 6. Changes in relative weight $(\mathrm{g} / 100 \mathrm{~g} B W)$ of pancreas, kidney and spleen of male diabetic(D) and non-diabetic rats treated with milk protein concentrate (MPC) and milk protein concentrate hydrolysate (MPCH).
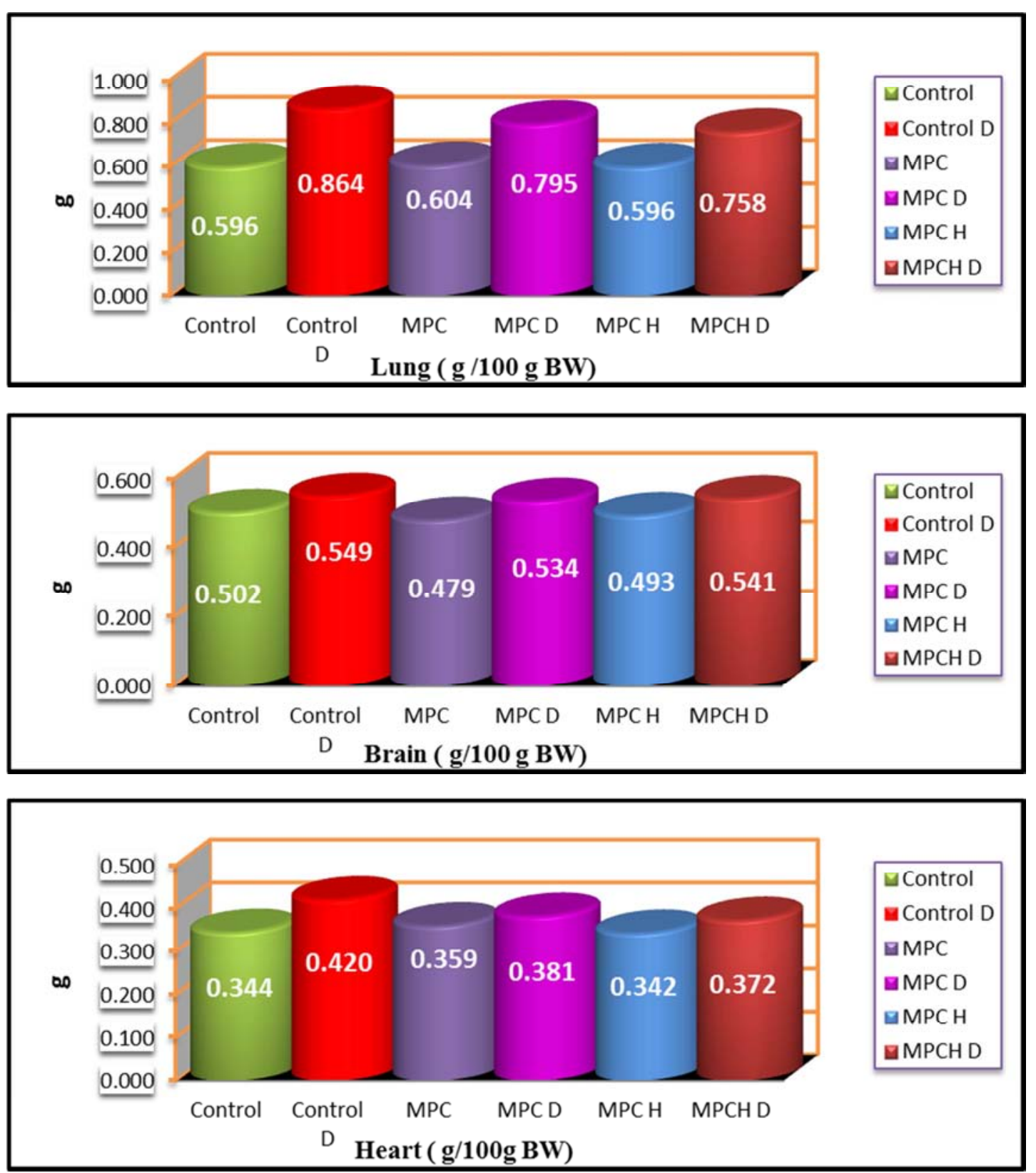


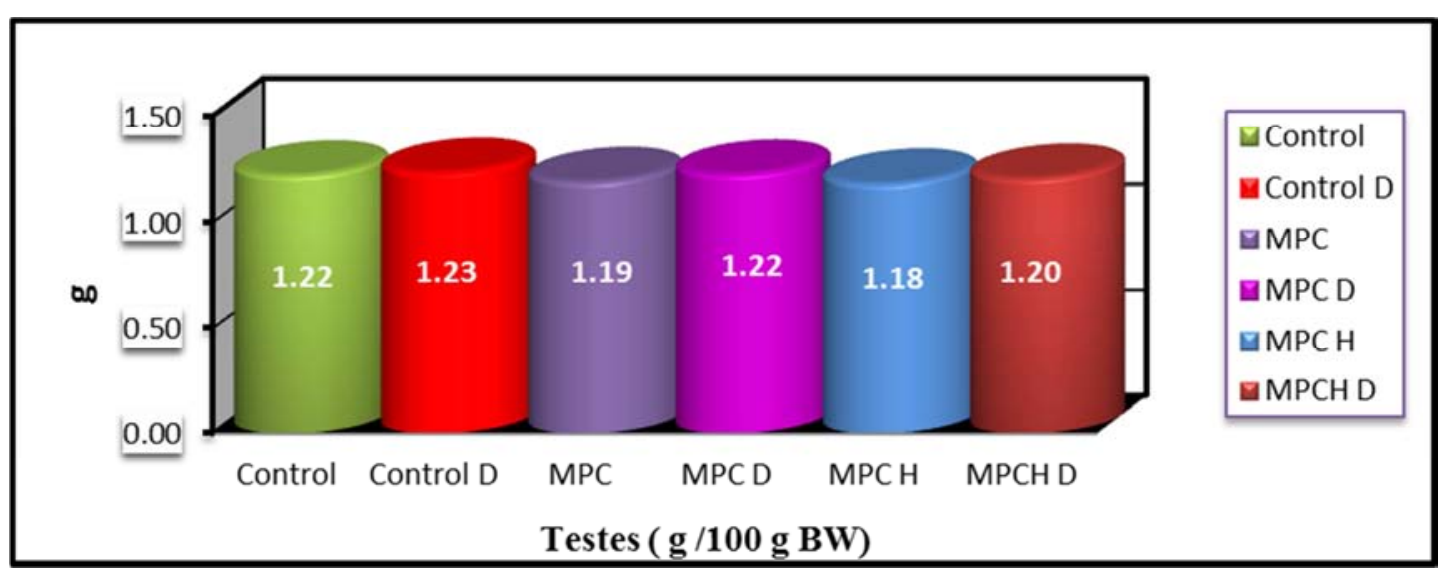

Figure 7. Changes in relative weight $(\mathrm{g} / 100 \mathrm{~g} \mathrm{BW})$ of heart, lung, brain and testes of male diabetic(D) and non-diabetic rats treated with milk protein concentrate (MPC) and milk protein concentrate hydrolysate (MPCH).

\subsection{Changes in Hematological Parameters of Diabetic and Non-Diabetic Rats}

Table (1) presents the distribution of red blood cells counts (RBC), Hemoglobin\% ( $\mathrm{Hb} \mathrm{g} / \mathrm{dl})$ and Hematocrit $(\mathrm{Ht} \%)$ in blood of diabetic and non-diabetic rats. The results showed that the $\mathrm{RBC}$ count, $\mathrm{Hb} \%$ and $\mathrm{Ht} \%$ of diabetic control rats were significant $(\mathrm{P}<0.05)$ decreased when compared to normal control rats. Both treatment agents (MPC and MPCH) showed a detectable amelioration of RBC count of diabetic rats and returned the values to normal range. Meanwhile, there were no significant $(\mathrm{P}>0.05)$ difference in $\mathrm{RBC}$ and $\mathrm{Ht}$ of non-diabetic rats treated by oral intake of MPC and MPCH when compared to control normal rates. While the treatment by oral intake of MPC and MPCH significant $(\mathrm{P}<0.05)$ increased the $\mathrm{Hb} \%$ of non-diabetic rats. Concerning to the Platelets count (PLT), the data present in Table (1) showed significant $(\mathrm{P}<0.05)$ decreasing of PLT in diabetic control group than that in all other groups. On the other hand, treatments with oral intake of MPC and MPCH of diabetic rats returned the values of the PLT to near the normal range of the control group. In addition, treatment with oral intake of $\mathrm{MPCH}$ of normal healthy rats had no significant $(\mathrm{P}>0.05)$ difference in values of PLT, while the treatment with MPC significant $(\mathrm{P}<0.05)$ decreased the PLT compared to control. Table (2) presents the distribution of red cell distribution width (RDW), mean cell volume (MCV), mean corpuscular hemoglobin $(\mathrm{MCH})$ and mean corpuscular hemoglobin concentration $\mathrm{MCHC}$ in blood of diabetic and non-diabetic rats treated by oral intake of MPC and MPCH. The results showed significant $(\mathrm{P}<0.05)$ increasing in red cell distribution width (RDW) with the diabetic control group when compared to normal control rats. Meanwhile, there were no significant $(\mathrm{P}<0.05)$ differences among normal control and all other treated groups. The mean cell volume (MCV) values are presented in Table (1). There is no significant $(\mathrm{P}>0.05)$ difference was observed between control and all other treated groups. Concerning to the mean corpuscular hemoglobin $(\mathrm{MCH})$, there were significant $(\mathrm{P}<0.05)$ decreasing of $\mathrm{MCH}$ in the diabetic control group when compared to other groups. While the $\mathrm{MCH}$ was significant $(\mathrm{P}<0.05)$ increased in normal and diabetic rats treated with MPC and MPCH when compared to control rates. The results showed that there was no significant $(\mathrm{P}>0.05)$ difference in mean corpuscular hemoglobin concentration MCHC values between normal control and diabetic control groups (Table 1).

Table 1. Changes in red blood cells count (RBC), hemoglobin\% (Hb g/dl), hematocrit (Ht\%), platelets count (PLT), red cell distribution width (RDW), mean cell volume (MCV), mean corpuscular hemoglobin $(M C H)$ and mean corpuscular hemoglobin concentration (MCHC) of male diabetic(D) and non-diabetic rats treated with milk protein concentrate (MPC) and milk protein concentrate hydrolysate (MPCH).

\begin{tabular}{lllllll}
\hline \multirow{2}{*}{ Parameters } & \multicolumn{7}{l}{ Experimental groups } & & & \\
\cline { 2 - 7 } & Control & Control D & MPC & MPC D & MPCH & MPCH D \\
\hline $\mathrm{RBC}^{*} 10^{6} / \mu \mathrm{l}$ & $8.40 \pm 0.076^{\mathrm{ab}}$ & $8.16 \pm 0.08^{\mathrm{b}}$ & $8.44 \pm 0.158^{\mathrm{ab}}$ & $8.34 \pm 0.114^{\mathrm{ab}}$ & $8.49 \pm 0.056^{\mathrm{a}}$ & $8.31 \pm 0.207^{\mathrm{ab}}$ \\
$\mathrm{Hbg} / \mathrm{dl}$ & $14.15 \pm 0.184^{\mathrm{c}}$ & $13.27 \pm 0.130^{\mathrm{d}}$ & $14.76 \pm 0.234^{\mathrm{a}}$ & $14.29 \pm 0.175^{\mathrm{bc}}$ & $14.55 \pm 0.064^{\mathrm{ab}}$ & $14.15 \pm 0.197^{\mathrm{c}}$ \\
$\mathrm{HT} \%$ & $45.25 \pm 0.479^{\mathrm{a}}$ & $42.75 \pm 0.854^{\mathrm{b}}$ & $45 \pm 0.707^{\mathrm{a}}$ & $44.91 \pm 0.417^{\mathrm{a}}$ & $44.25 \pm 1.031^{\mathrm{ab}}$ & $44 \pm 0.577^{\mathrm{ab}}$ \\
$\mathrm{PLT}$ & $575 \pm 6.45^{\mathrm{a}}$ & $453 \pm 6.02^{\mathrm{d}}$ & $547 \pm 4.93^{\mathrm{b}}$ & $530 \pm 6.39^{\mathrm{c}}$ & $572 \pm 6.46^{\mathrm{a}}$ & $548 \pm 5.34^{\mathrm{b}}$ \\
$\mathrm{RDW}$ & $17.1 \pm 0.147^{\mathrm{bc}}$ & $19.06 \pm 0.306^{\mathrm{a}}$ & $16.5 \pm 0.642^{\mathrm{c}}$ & $17.53 \pm 0.417^{\mathrm{b}}$ & $16.6 \pm 0.122^{\mathrm{c}}$ & $17.3 \pm 0.523 \mathrm{~b}^{\mathrm{c}}$ \\
$\mathrm{MCV}$ & $53.25 \pm 0.751^{\mathrm{a}}$ & $52.1 \pm 0.443^{\mathrm{a}}$ & $52.1 \pm 0.696^{\mathrm{a}}$ & $52.65 \pm 0.312^{\mathrm{a}}$ & $52.13 \pm 0.379^{\mathrm{a}}$ & $52.9 \pm 0.780^{\mathrm{a}}$ \\
$\mathrm{MCH}$ & $16.85 \pm 0.096^{\mathrm{bc}}$ & $16.45 \pm 0.119^{\mathrm{d}}$ & $16.75 \pm 0.21^{\mathrm{cd}}$ & $17.16 \pm 0.062^{\mathrm{ab}}$ & $17.3 \pm 0.212^{\mathrm{a}}$ & $17.32 \pm 0.193^{\mathrm{a}}$ \\
$\mathrm{MCHC}$ & $31.5 \pm 0.227^{\mathrm{b}}$ & $31.36 \pm 0.12^{\mathrm{b}}$ & $32.33 \pm 0.165^{\mathrm{a}}$ & $32.3 \pm 0.227^{\mathrm{a}}$ & $32.43 \pm 0.184^{\mathrm{a}}$ & $32.17 \pm 0.347^{\mathrm{a}}$ \\
\hline
\end{tabular}

Values are expressed as means $\pm \mathrm{SE} ; \mathrm{n}=7$ for each treatment group.
Mean values within a row not sharing a common superscript letters ( $\mathrm{a}, \mathrm{b}, \mathrm{c}, \mathrm{d})$ were significantly different, 
$\mathrm{p}<0.05$.

While the oral intake of MPC and MPCH significant $(\mathrm{P}<0.05)$ increased the $\mathrm{MCHC}$ of normal and diabetic rats when compared to controls. Table (2) presents the distribution of white blood cell count (WBC), Lymphocytes, Segmented Nutrophils, Monocytes and Eosinophils in blood of diabetic and non-diabetic rats treated by oral intake of MPC and MPCH. There were significant $(\mathrm{P}<0.05)$ increasing of $\mathrm{WBC}$ in diabetic control group when compared to other treated groups. While there were no significant $(\mathrm{P}>0.05)$ difference between control normal group and all other treated groups. The percentage of Lymphocytes was a significant $(\mathrm{P}<0.05)$ decreased in the diabetic control and significant $(\mathrm{P}<0.05)$ increased in normal group treated by MPC. On the other hand, there were no significant $(\mathrm{P}>0.05)$ difference among normal control group and normal rates treated by $\mathrm{MPCH}$, diabetic rats treated by $\mathrm{MPCH}$ and MPC. Treated animals with alloxan alone showed a significant increasing $(p<0.05)$ in percentage of blood segmented nutrophils and monocytes. Meanwhile, treatment with oral intake MPC and $\mathrm{MPCH}$ of diabetic rats returned these values to be near the normal value of control group. However, there is no significant $(\mathrm{P}>0.05)$ difference in blood $\mathrm{S}$. Nutrophils level of normal rats treated by oral intake of MPC and MPCH when compared with control group. On the other hand, Eosinophils value was significant $(\mathrm{P}<0.05)$ decreased with diabetic control group when compared to normal control. On the other side, the treatment with oral intake MPC and MPCH of diabetic rats returned these values to be similar to the normal value of control group. In addition, the treatment with the oral intake of MPC and MPCH of normal healthy rats significantly $(\mathrm{P}<0.05)$ increased the Eosinophils of $\mathrm{MPCH}$ group and there is no significant $(\mathrm{P}>0.05)$ difference between MPC group and control group.

Table 2. Changes in white blood cell count WBC, lymphocytes, segmented neutrophils, monocytes, and eosinophils of male diabetic (D) and non-diabetic rats treated with milk protein concentrate $(M P C)$ and milk protein concentrate hydrolysate $(M P C H)$.

\begin{tabular}{|c|c|c|c|c|c|c|}
\hline \multirow{2}{*}{ Parameters } & \multicolumn{6}{|c|}{ Experimental groups } \\
\hline & Control & Control D & MPC & MPC D & МРCH & MPCH D \\
\hline $\mathrm{WBC}^{*} 10^{3} / \mu \mathrm{l}$ & $8.73 \pm 0.411^{\mathrm{b}}$ & $10.65 \pm 0.708^{\mathrm{a}}$ & $8.8 \pm 0.730^{b}$ & $9.25 \pm 0.176^{\mathrm{b}}$ & $8.66 \pm 0.478^{b}$ & $8.96 \pm 0.464^{b}$ \\
\hline Lymphocytes $\%$ & $76.5 \pm 1.44^{\mathrm{b}}$ & $73.25 \pm 0.479^{\mathrm{c}}$ & $80.25 \pm 1.65^{\mathrm{a}}$ & $75.77 \pm 2.11^{\mathrm{bc}}$ & $76 \pm 0.816^{\mathrm{bc}}$ & $76.07 \pm 1.08^{\mathrm{bc}}$ \\
\hline Segmented Neutrophils\% & $15 \pm 0.408^{\mathrm{c}}$ & $17.32 \pm 0.624^{\mathrm{a}}$ & $15.32 \pm 0.624^{\mathrm{bc}}$ & $16.5 \pm 0.645^{\mathrm{ab}}$ & $15 \pm 0.707^{\mathrm{c}}$ & $15.75 \pm 0.854^{\mathrm{bc}}$ \\
\hline Monocytes\% & $4.67 \pm 0.236^{\mathrm{ab}}$ & $5.38 \pm 0.375^{\mathrm{a}}$ & $5 \pm 0.408^{\mathrm{ab}}$ & $5 \pm 0.408^{\mathrm{ab}}$ & $4.5 \pm 0.204^{b}$ & $4.38 \pm 0.239^{\mathrm{b}}$ \\
\hline Eosinophils\% & $2.75 \pm 0.25^{\mathrm{ab}}$ & $2.3 \pm 0.178^{b}$ & $2.75 \pm 0.25^{\mathrm{ab}}$ & $2.7 \pm 0.071^{\mathrm{ab}}$ & $3 \pm 0.204^{\mathrm{a}}$ & $2.75 \pm 0.250^{\mathrm{ab}}$ \\
\hline
\end{tabular}

Values are expressed as means $\pm \mathrm{SE} ; \mathrm{n}=7$ for each treatment group

Mean values within a row not sharing a common superscript letters (a, b, c, d) were significantly different, $\mathrm{p}<0.05$.

SDS-PAGE of plasma proteins

The effect of oral intake of milk protein concentrate

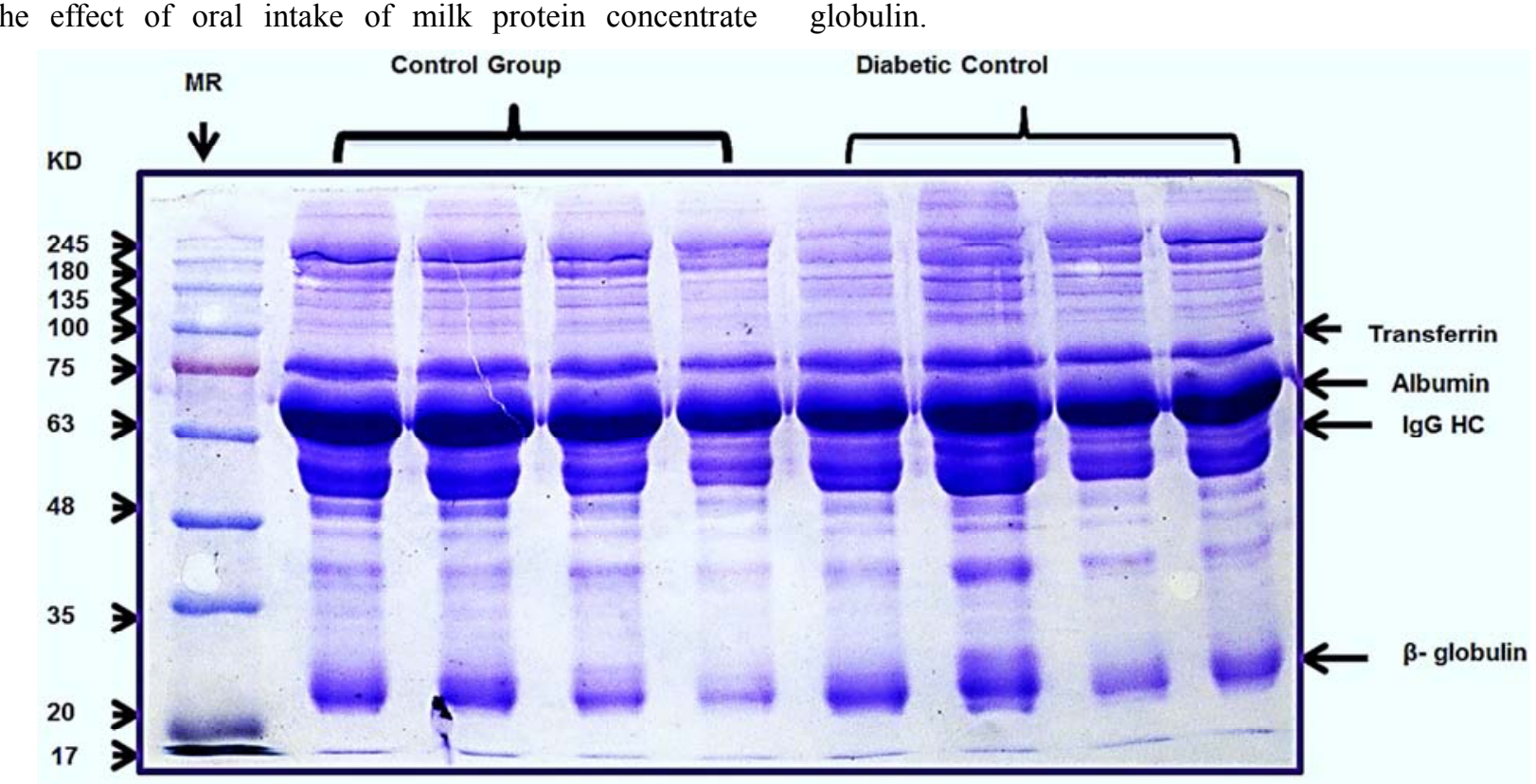

(A)
(MPC) and milk protein concentrate hydrolysate (MPCH) on plasma proteins were mentioned by SDS- PAGE technique (Figure 8). The obtained results recommended that the all treatments have no effect on the behavior of plasma proteins, as there were no difference between the pattern of all treated groups in migration and concentration of albumin and globulin.

Diabetic Control 


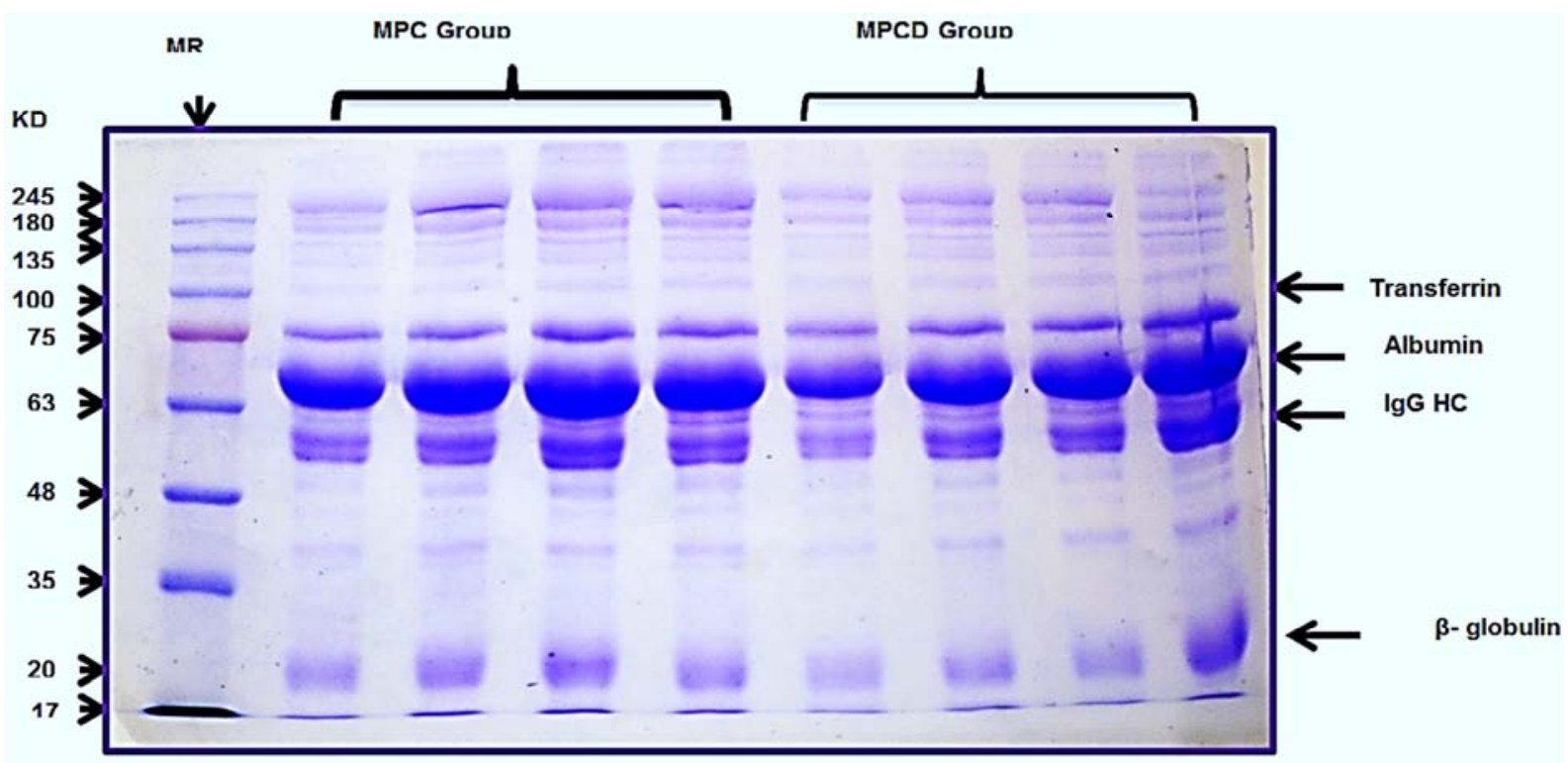

(B)

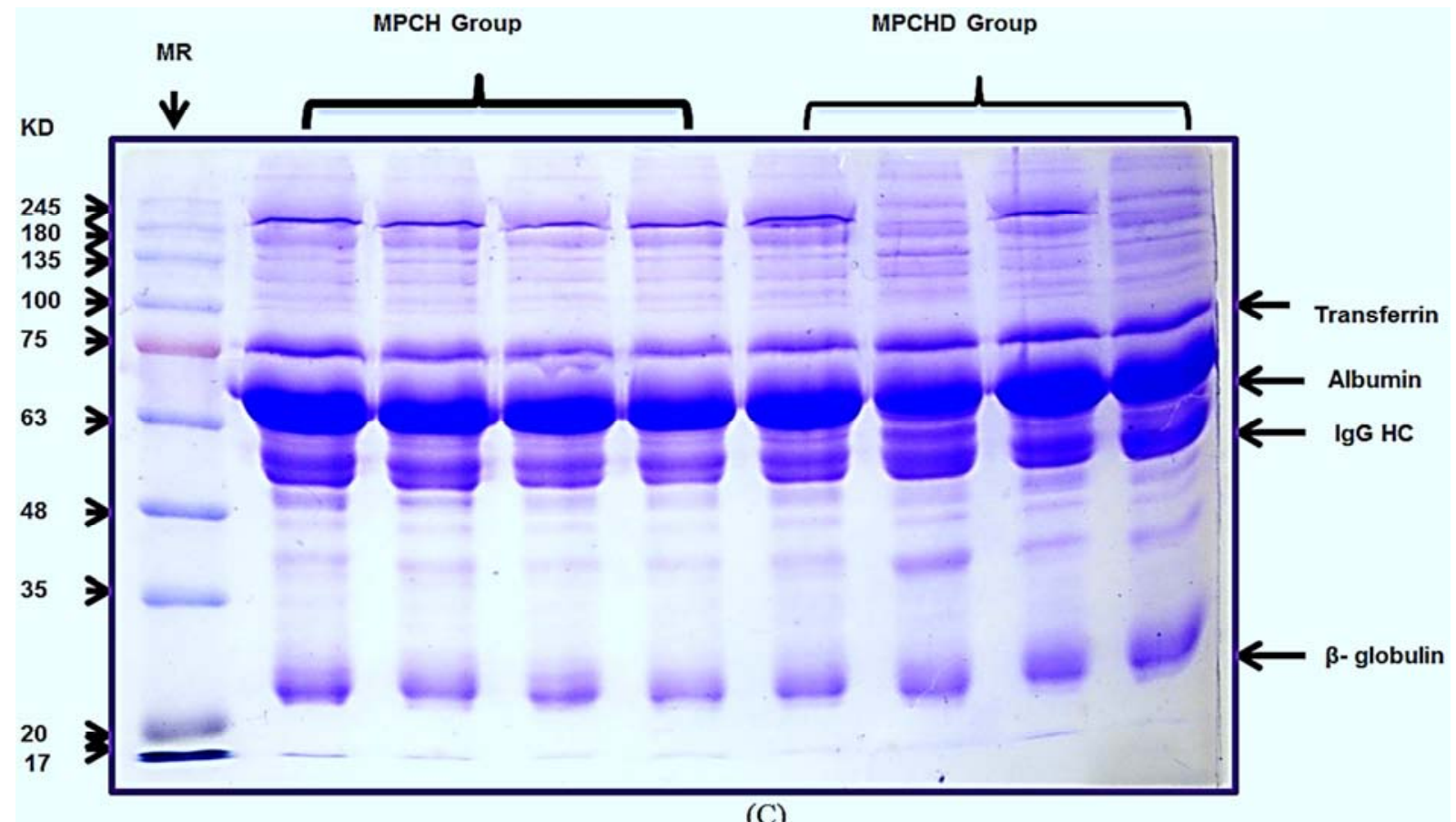

(C)

Figure 8. SDS-PAGE (10\% T) of blood plasma (A) control and diabetic control group, (B) MPC and MPC D groups and (C) MPCH and MPCH D groups.

\section{Discussion}

Treatment of rats with alloxan alone caused a significant $(p<0.05)$ decreasing in body, pancreas weights, and increasing in liver, kidney, heart and lung relative weights. These results were agreed with Zhang et al. [29]. Treated animals with alloxn alone showed a significant increasing $(p<0.05)$ in percentage of blood segmented nutrophils and monocytes. Meanwhile, treatment with oral intake MPC and MPCH of diabetic rats returned these values to be near the normal value of the control group. However, there is no significant $(\mathrm{P}>0.05)$ difference in blood $\mathrm{S}$. Nutrophils level of normal rats treated by oral intake of MPC and MPCH when compared with control group. On the other hand, Eosinophils value was significant $(\mathrm{P}<0.05)$ decreased with diabetic control group when compared to normal control. On the other side, the treatment with oral intake MPC and MPCH of diabetic rats returned these values to be similar to the normal value of the control group. In addition, the treatment with the oral intake of MPC and MPCH of normal healthy rats significantly $(\mathrm{P}<0.05)$ increased the Eosinophils of $\mathrm{MPCH}$ group and there is no significant $(\mathrm{P}>0.05)$ difference between MPC group and control group. Most of the obtained results are in agreement with Helal et al.[30], who found a 
highly significant decrease $(\mathrm{p}<0.01)$ in $\mathrm{RBCs}$ count, $\mathrm{Hb}$ concentration and $\mathrm{Ht}$ value in diabetic rats compared with that in control group. Concerning to the white blood cell count, there were a significant increasing $(\mathrm{p}<0.01)$ in diabetic group when compared to control group. There were insignificant changes in the percentage of eosinophils, monocyte and staff neutrophils in diabetic group compared to the normal control. Lymphocytes showed a highly significant $(p<0.01)$ decrease when compared with control group throughout the experimental period. Also, Mahmoud [31] found that diabetic group showed non-significant change $(\mathrm{P}>$ $0.05)$ in the percentage of eosinophils, however, there was a significant increase $(\mathrm{P}<0.01)$ in neutrophils, monocytes and basophils. On the other hand, lymphocytes showed a significant decrease $(\mathrm{P}<0.01)$ when compared with normal control group throughout the experimental period. In addition, he found that $\mathrm{RBC}, \mathrm{Hb}, \mathrm{MCHC}, \mathrm{MCH}, \mathrm{PCV}$ and $\mathrm{MCV}$ of control diabetic was the lowest that of control. The link between chronic diseases and anemia is well characterized [32]. The occurrence of anemia in diabetes mellitus has been reported due to the increased nonenzymatic glycosylation of RBC membrane proteins, which correlates with hyperglycemia [33]. Oxidation of these proteins and hyperglycaemia in diabetes mellitus causes an increase in the production of lipid peroxides that lead to hemolysis of RBC [34].

Our results showed that diabetic rats recorded a decrease in $\mathrm{RBCs}$ count, $\mathrm{Hb}$ content and Hct value.These rats suffered from anemia, which may be resulting from the toxic effect of alloxan used to induce diabetes in these rats. This anemia could be attributed to destruction of RBCs and reduced rate of its release from the bone marrow to the blood. Several studies attributed this anemia to increase in lipid peroxidation of the erythrocyte cell membrane $[35,36]$. The increasing of neutrophil number may be due the engagement of these cells in the phagocytic process against different antigens. The increase in neutrophils also may be due to decrease its phagocytic activity in hyperglycemia and due to increase in hemopoitic activity after releasing the granules of neutrophil by exocytosis to lyses the antigens extra-cellularly [37].

\section{Conclusion}

Treatment of rats with alloxan alone caused a significant $(p<0.05)$ decreasing in body, pancreas weights, and increasing in liver, kidney, heart and lung relative weights. However, brain, spleen and testes weights were not affected when compared with control. Intra-gastric treatment by MPC and MPCH significantly $(P<0.05)$ increased the final body weight of normal rats and improved the body weight of diabetic rats and significantly protective $(p<0.05)$ the liver, kidney, heart and lung of normal rats and reduced the failures of these organs in diabetic rats. The diabetes groups treated by $\mathrm{MPCH}$ showed improvement in $\mathrm{RBC}, \mathrm{Hb}, \mathrm{Ht}$ and PLT values. Meanwhile WBC not affected. The oral intake of MPCH protected the normal range of Lymphocytes and S. Nutrophils in healthy and diabetic rats. The oral intake of
MPCH caused significantantly $(P<0.05)$ decrease of Monocytes in diabetic and non-diabetic rats, while the oral intake of MPC had no affected on Monocytes of diabetic and non-diabetic rats. From these results it can be concluded that the milk protein concentrate hydrolysate $(\mathrm{MPCH})$ is characterized by a high biological value such as protective the hematological parameters in normal and diabetic rats and reduce the stress on various organs of the body because of diabetes.

\section{References}

[1] Harlev E, E. Nevo, N. Mirsky and R. Ofir, 2013. Antidiabetic attributes of desert and steppic plants: a review. Planta Medica, 79: 425-436.

[2] Mirmiran P, Z. Bahadoran, F. Azizi, 2014. Functional foodsbased diet as a novel dietary approach for management of type 2 diabetes and its complications: A review. World Journal of Diabetes, 5: 267- 281.

[3] Schrezenmeir, J. and A. Jagla, 2000. Milk and diabetes. Journal of the American College of Nutrition, Vol. 19, No. 2: 176S-190S.

[4] WHO, 2006. Definition and diagnosis of diabetes mellitus and intermediate hyperglycemia: report of a WHO/IDF consultation.

[5] Tamrakara, A. K., N. Jaiswala., P. P. Yadavb., R. Mauryab. and A.K. Srivastavaa, 2011. Pongamol from Pongamiapinnata stimulates glucose uptake by increasing surface GLUT4 level in skeletal muscle. Molecular and Cellular Endocrinology, 339: 98-104.

[6] Hirahatake K. M, J. L. Slavin, K. C. Maki and S. H. Adams, 2014. Associations between dairy foods, diabetes, and metabolic health: potential mechanisms and future directions. Metabolism, 63: 618-627.

[7] Sun, X and M.B. Zemel. 2006. Dietary calcium regulates ROS production in aP2-agouti transgenic mice on high-fat/ highsucrose diets. International Journal of Obesity, 230: 13411346.

[8] Jakubowicz, D and O. Froy, 2013. Biochemical and metabolic mechanisms by which dietary whey protein may combat obesity and Type 2 diabetes. The Journal of Nutritional Biochemistry, 24: 1-5.

[9] Yan, J., Zhao, J., Yang R and Zhao, W, 2019. Bioactive peptides with antidiabetic properties: a review. International Journal of Food Science and Technology. doi:10.1111/ijfs. 14090

[10] Awad, S, M.I. El-Sayed, A. Wahba, A. El Attar, M. I. Yousef and M. Zedan, (2016). Antioxidant activity of milk protein hydrolyaste in alloxan-induced diabetic rats. Journal of Dairy Science, 99: 8499-8510.

[11] Korhonen, H., and A. Pihlanto, 2003. Food-derived bioactive peptides opportunities for designing future foods. Current Pharmaceutical Design, 9: 1297-1308.

[12] Hartmann, R., H. Meisel, 2007. Food-derived peptides with biological activity: from research to food applications. Curr. Opin. Biotechnol, 18: 163-169. 
[13] Hajirostamloo, B, 2010. Bioactive component in milk and dairy product. World academy of science, Engineering and Technology, 72: 162-166.

[14] Plaisanciéa, P., J. Claustrec., M. Estiennea., G. Henryd., R. Boutroud., A. Paqueta and J. Léonild, 2013. A novel bioactive peptide from yoghurts modulates expression of the gelforming MUC2 mucin as well as population of goblet cells and Paneth cells along the small intestin. Journal of Nutritional Biochemistry, 24: 213-221.

[15] Marcone S., Belton, O \& Fitzgerald D. J, 2017. Milk-derived bioactive peptides and their health promoting effects: a potential role in atherosclerosis. British Journal of Clinical Pharmacology, 83: 152-162.

[16] Kamau, S. M., R.R. Lu., W. Chen, X.M. Liu., F. W. Tian., Y.Shen and T. Gao, 2010. Functional significance of bioactive peptides derived from milk proteins. Food Reviews International, 26: 386-401.

[17] Guilloteau, P., V. Rome'., L. Delaby., F. Mendy., L. Roger and J. A. Chayvialle, 2009. A new role of phosphopeptides as bioactive peptides released during milk casein digestion in the young mammal: Regulation of gastric secretion. Peptides; 30: 22212227.

[18] Pan, D. D., Z. Wu., J. Liu., X. Y. Cao and X. Q. Zeng, 2013. Immunomodulatory and hypoallergenic properties of milk protein hydrolysates in ICR mice. Journal of Dairy Science., 96: 49584964.

[19] Mansour, H. A., A. S. Newairy., M. I. Yousef and S. A. Sheweita, 2002. Biochemical study on the effects of some Egyptian herbs in alloxan-induced diabetic rats. Toxicology, 170 (3): 221-228.

[20] Sheweita, S. A., A. A. Newairy., H. A. Mansour and M. I. Yousef, 2002. Effect of some hypoglycemic herbs on the activity of phase I and II drug-metabolizing enzymes in alloxan-induced diabetic rats. Toxicology, 174: 131-139.

[21] Otte, J., S. M. Shalaby., M. Zakora., A. H. Pripp and S. A. El-Shabrawy, 2007. Angiotensin-converting enzyme inhibitory activity of milk protein hydrolysates: Effect of substrate, enzyme and time of hydrolysis. International Dairy Journal, 17: 488-503.

[22] El-Sayed, M. I, S. Awad., A.Wahba., A. El Attar., M.I. Yousef and M. Zedan, 2016. In Vivo Anti-diabetic and Biological Activities of Milk Protein and Milk Protein Hydrolyaste. Advances in.Dairy,Research, 1000154.

[23] Laemmli, U. K, 1970. Cleavage of structural proteins during the assembly of the head of bacteriophage T4. Nature, 277: 680-685.

[24] Hames, B. D. and D. Rickwood, 1990. In: Gel electrophoresis of proteins. A practical approach. TRL, London, England. Puplishing Co.pp.34, 36, 37, 44, 45 and 48.

[25] Awad, S., Q. Q. Lúthi-Peng and Z. Puhan, 1998. Proteolytic activities of chymosin and porcine pepsin on buffalo, cow, and goat whole and $\beta$-Casein fractions. Journal of Agriculture and Food Chemistry, 46: 4997-5007.

[26] AOAC. (2005) Official Methods of Analysis of AOAC International. (18th ed.) Gaithersburg.

[27] Childs, A. C., S. L. Phaneuf., A. J. Dirks., T. Phillips and C. Leeuwenburgh, 2002. Doxorubicin treatment in vivo causes cytochrome $\mathrm{C}$ release and cardiomyocyte apoptosis, as well as increased mitochondrial efficiency, superoxide dismutase activity, and Bcl-2: Bax ratio. Cancer Res; 62: 4592-4598.

[28] Zhang, H., Wang, J., Liu, Y\& Sun B, (2015). Peptides Derived from Oats Improve Insulin Sensitivity and Lower Blood Glucose in Streptozotocin-Induced Diabetic Mice. Journal of Biomedical Sciences, 4: 1-7.

[29] SAS (2004).SAS Procedure Guide "Version 6.12 Ed." SAS Institute Inc., Cary.

[30] Helal, E. G. E., A. S. M. Gawish and A. Kahwash, 2005. Some hematological- studice on diabetic rats - treated with certain hypoglycemic plants. The Egyptian Journal of Hospital Medicine, 19: 179 - 188.

[31] Mahmoud, A.M, 2013. Hematological alteration in diabetic rats-role of adipocytokines and effect of citrus flavonoids. EXCLI Journal, 12: 647- 657.

[32] Weiss, G. and L. T. Goodnough, 2005. Anemia of chronic disease. N Engl J Med; 352: 1011-23.

[33] Oyedemi, S. O., M. T. Yakubu and A. J. Afolayan, 2011. Antidiabetic activities of aqueous leaves extract of Leonotis leonurus in streptozotocin induced diabetic rats. J. Med. Plant Res., 5: 119-125.

[34] Arun, G. S. and K. G. Ramesh, 2002. Improvement of insulin sensitivity by perindopril in spontaneously hypertensive and streptozotocindiabetic rats. Indian J Pharmacol, 34: 156- 64.

[35] Kang-xin., F., Yunzhong., Xin-Wanjuan and P.U. Sunchunr, (1990). Observation on the effect of irradiation in vitro and in vivo on SH- group of rat erythrocyte membrane by spine label technique. J. Radia. Res. and Radia process, 8 (2): 103-112.

[36] Helal, E. G. E, 2000. Effectiveness of an herbal mixture with treatment of noninsulin dependent diabetes mellitus. Al-Azhar Bull. Sc., 1: 201- 324.

[37] Ganong, W. F, 2003. Review of medical physiology 23rd ed., Lange med. Public, 19: 306-326. 